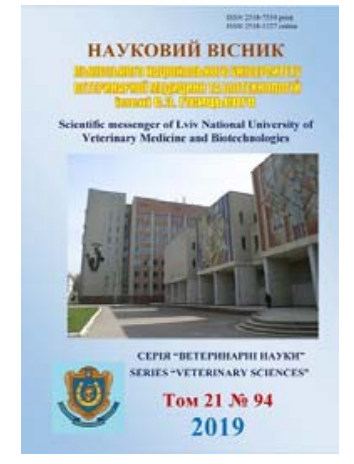

Науковий вісник Дьвівського національного університету ветеринарної медицини та біотехнологій імені С.3. Гжицького.

\author{
Серія: Ветеринарні науки
}

Scientific Messenger of Lviv National University of Veterinary Medicine and Biotechnologies. Series: Veterinary sciences

UDC 619:616.995:636.92

\title{
Nonspecific reactivity of the rabbits organism when exposed to cysticercosis
}

\author{
Y.V. Duda \\ Dnipro State Agrarian and Economic University, Dnipro, Ukraine
}

Article info

Received 22.04.2019

Received in revised form 21.05 .2019

Accepted 22.05.2019

Dnipro State Agrarian and Economic University, Serhiya Yefremova Str., 25, Dnipro, 49000, Ukraine.

Tel.: +38-067-781-54-69.

E-mail: dudajulia1976@gmail.com
Duda, Y.V. (2019). Nonspecific reactivity of the rabbits organism when exposed to cysticercosis. Scientific Messenger of Lviv National University of Veterinary Medicine and Biotechnologies. Series: Veterinary sciences, 21(94), 132-135. doi: 10.32718/nvlvet9424

One of the actual rabbits breeding problem is the reduction of their resistance, which is caused by the spread of individual invasive diseases, especially cysticercosis, which is caused by the larval Cysticercus pisiformis stage of the mature cestode Taenia pisiformis. The study was conducted on 38 male rabbits age 3-4 months, weighing 3.5-4.0 kg of the Californian breed, selected by analogy. Animal were separated into two groups: healthy animals (control group) and sick animals (research group). After blood collection, slaughter was conducted and the presence of cysticercus cysts was visually determined in the organisms of the rabbits. Control animals received a balanced standard granular feed and water without limit; research group in addition to the standard granulated feed with water received flaccid hay. The animals were kept in mesh single-tier cages in the room, according to the current veterinary and sanitary standards. The definition of phagocytic activity of neutrophils was carried out with the addition of standardized to 2500000000/ml suspension of daily culture of E. coli 055K59№3912/41. The bactericidal activity of blood serum was determined by the method Smirnova A.V. and Kuzmina T.A. in relation to the E. coli microbial test-culture 055K59№3912/41. The serum lysozyme activity was determined by the Nephelometric method using the Dorofachuk V.G. method to the microbial test culture Micrococcus luteus ATSS9341. Circulating immune complexes were determined using polyethylene glycol in borate buffer (pH 8.4). It was found that in blood of sick animals phagocytic activity is lower than in blood of healthy ones (respectively, $41.82 \pm 1.51 \%$ versus $47.38 \pm 1.10 \%, P<0.01)$. The main cells involved in phagocytosis are leukocytes, in particular neutrophils and eosinophils. A low indicator of phagocytic activity shows depressed phagocytosis in the organism of animals suffering from cysticercosis of rabbits. The phagocytic number in the blood of rabbits of the experimental group was significantly lower by 0.51 units $(P<0.05)$ as compared to the control group and correlated with the index of phagocytic activity. An important element of immunity are indicators of bactericidal and lysozyme activity of blood serum. Low bactericidal activity of serum by $12.88 \%(P<0.01)$ and lysozyme activity in rabbits with Cysticercus pisiformis also indicates a weakening of the factors of nonspecific natural resistance of the organism. Analyzing the level of circulating immune complexes, we found a high level of medium (9.14 \pm 0.40 vs $5.58 \pm 0.50)$ and small $(9.21 \pm 1.35$ vs $4.64 \pm 0.68)$ CIC for cysticercosis, respectively, $1.64(P<0.01)$ and 1.98 times $(P<0.001)$ against the control. This indicates the inhibition of the immunobiological activity in the organism of rabbits as a result of the combination of specific antibodies with the products of the exchange of helminths.

Key words: phagocytic, lysozyme and bactericidal activity, CIC, cysticercosis invasion, Cysticercus pisiformis, rabbit.

\section{Неспецифічна реактивність організму кролів за впливу цистицеркозної інвазії}

Ю.В. Дуда

Дніпровський державний аграрно-економічний університет, м. Дніпро, Україна 
Однією з найактуальніших проблем за вирощування кролів є зниження їх резистентності, щзо зумовлено поширенням окремих інвазійних захворювань, передусім цистицеркозу, який викликається личинковою стадією Cysticercus pisiformis статевозрілої иестоди Taenia pisiformis. Дослідження проведено на 38 кролях-самиях 3-4-місячного віку, масою тіла 3,5-4,0 кг каліфорнійської породи відібраних за принципом аналогів. Тварин утримували в сітчастих одноярусних клітках у приміщенні, згідно з чинними ветеринарно-санітарними нормами. Тварини були поділені на дві групи: контрольні тварини (здорові тварини), щяо отримували збалансований стандартний гранульований комбікорм і воду без обмеження; дослідні (хворі тварини), які крім стандартного гранульованого комбікорму з водою, додатково, споживали прив'ялене сіно. Після взяття крові проводили забій та візуально визначали кількість цистицеркозних міхурів у кролів. Визначення фагоцитарної активності нейтрофілів здійснювали з додаванням стандартизованого до 2 млрд/мл завису добової культури E. coli 055K59 № 3912/41. Бактерицидну активність сироватки крові визначали методом Смірнової О.В. та Кузьміної Т.А. за відноченням мікробної тест-культури Е. софі 055К59 № 3912/41. Лізочиимну активність сироватки крові визначали нефелометричним методом за Дорофейчуком В.Г. за відношенням до мікробної тесткультури Micrococcus luteus ATCС9341. Циркулюючи імунні комплекси визначали за допомогою поліетиленгліколю в боратному буфері (рН 8,4). При вивченні фагоцитарної активності виявлено, щуо у клінічно хворих тварин вона нижча, ніж у здорових (відпо-

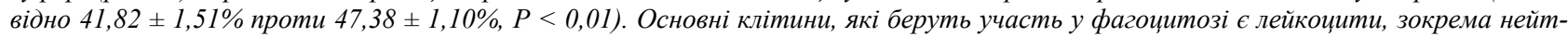
рофіли та еозинофіли. Низький показник фагоцитарної активності свідчить про пригнічений фагоцитоз в організмі тварин, хворих на циистицеркоз кролів. Фагоцитарне число у крові кролів дослідної групи вірогідно було нижче на 0,51 одиниці (P < 0,05) порівняно з контролем і корелювали з показником фагочитарної активності. Важливою ланкою імунітету є показники бактерицидної та лізоцимної активності сироватки крові. Низька бактерицидна активність сироватки крові на 12,88\% (P < 0,01) та лізоцимна активність у кролів, хворих на Cуsticercus pisiformis, також свідчить про послаблення факторів неспециифічної природної резистентності організму. Аналізуючи рівень цииркулюючих імунних комплексів, ми встановили високий рівень середніх (9,14 \pm 0,40 проти $5,58 \pm 0,50)$ та дрібних $(9,21 \pm 1,35$ проти 4,64 $\pm 0,68)$ ЦІК за ичистицеркозної інвазії відповідно в 1,64 (P < 0,01) та 1,98 разу $(P<0,001)$ проти контролю. Це свідчить про пригнічення імунобіологічної активності організму кролів внаслідок з'єднання специфічних антитіл з продуктами обміну гельмінтів.

Ключові слова: фагоцитарна, лізоцимна та бактериџидна активність, ЦІК, цистицеркозна інвазія, Суsticercus pisiformis, кролі.

\section{Вступ}

Рівень природної резистентності характеризує ступінь стійкості організму до захворювань, на який впливають такі чинники, як вік тварини, пори року, умови годівлі та утримання (Drouet-Viard \& FortunLamothe, 2002; Kosenko et al., 2004; Jeklova et al., 2007). До показників природної резистентності відносять фагоцитарну активність нейтрофілів, бактерицидну активність сироватки крові і лізоцимну активність сироватки крові (Das et al., 2004; Blach-Olszewska \& Jerzy, 2007).

Схильність тварин до захворювання та характер його перебігу регулюється рівнем природної резистентності (Franci et al., 1996; Dasso \& Howell, 1997; Maslianko et al., 2011). Основою імунної системи є фагоцитарні властивості нейтрофілів, бактерицидна активність сироватки крові, імуноглобуліни та Т- і Влімфоцити (Mannapova \& Podushkina, 2001; Haitov \& Pinegin, 2005).

Однією 3 найактуальніших проблем за вирощування кролів $є$ зниження їхньої резистентності, що зумовлено поширенням окремих інвазійних захворювань, передусім цистицеркозу, який викликається личинковою стадією Cysticercus pisiformis статевозрілої цестоди Taenia pisiformis. Під час міграції онкосфер через слизову оболонку воротною веною або лімфатичними судинами до печінки та інших органів і тканин відбуваються суттєві зміни. Через 26 днів більшість цистицерків проникають через серозний покрив печінки і випадають у черевну порожнину, прикріплюються до сальника, поперекової або тазової частини прямої кишки, рідше - на очеревині і плеврі, де через 2-2,5 місяця вони досягають інвазійної стадії. Під час міграції личинкових форм цистицеркозу впливають на природну резистентність, але ступінь цього впливу на сьогодні науковцями в повній мірі не описана, тому залишається актуальним i потребує глибшого вивчення.

Метою роботи було проаналізувати впив цистицеркозної інвазії на показники неспецифічної реактивності організму кролів. Щоб досягти поставленої мети, треба було розв'язати декілька завдань: визначити фагоцитарну активність, фагоцитарний індекс і фагоцитарне число; дослідити бактерицидну та лізоцимну активності; встановити ЦІК.

\section{Матеріали і методи досліджень}

Робота виконувалась впродовж 2016 року. Дослідження проведено на 38 кролях-самцях 3-4-місячного віку, масою тіла 3,5-4,0 кг каліфорнійської породи відібраних за принципом аналогів у кролівницькому господарстві ТОВ “Олбест” Дніпропетровської області. Тварин утримували в сітчастих одноярусних клітках у приміщенні, згідно з чинними ветеринарносанітарними нормами. Тварини були поділені на дві групи: контрольні тварини (здорові тварини), що отримували збалансований стандартний гранульований комбікорм і воду без обмеження; дослідні (хворі тварини), які, крім стандартного гранульованого комбікорму 3 водою, додатково споживали прив'ялене сіно. Зразки крові у кролів відбирали вранці, з крайової вушної вени. Після взяття крові проводили забій та візуально визначали кількість цистицеркозних міхурів у кролів.

Лабораторні дослідження проводили в лабораторії кафедри паразитології та ветсанекспертизи Дніпровського державного аграрно-економічного університету.

Визначення фагоцитарної активності нейтрофілів (Lapovets et al., 2008; Vlizlo et al., 2012) здійснювали 3 додаванням стандартизованого до 2 млрд/мл завису добової культури E. coli 055К59 № 3912/41. У кожному мазку підраховували 100 нейтрофілів. В 
якості показників фагоцитозу визначали фагоцитарну активність за кількістю активних лейкоцитів 3100 підрахованих (\%). Фагоцитарний індекс (ФI) - за кількістю фагоцитованих мікробних тіл, що припадає на один активний нейтрофіл i характеризує поглинаючу здатність фагоцитів. Фагоцитарне число (ФЧ) - кількість фагоцитованих мікробних тіл на 100 підрахованих нейтрофілів.

Бактерицидну активність сироватки крові визначали методом Смірнової О.В. та Кузьміної Т.А. за відношенням мікробної тест-культури E. coli 055К59 № 3912/41 (Vlizlo et al., 2012).

Лізоцимну активність сироватки крові визначали нефелометричним методом за Дорофейчуком В.Г. (Dorofejchuk, 1968) за відношенням до мікробної тесткультури Micrococcus luteus АТСС9341.

Визначення рівня циркулюючих імунних комплексів (ЦІК) проводили методом диференційованої пре- ципітації в 3,5\% та 7,0\% розчині поліетиленгліколю 3 молекулярною масою 6000 дальтон (Franci et al., 1996).

При роботі 3 тваринами дотримувалися вимог “Свропейської конвенції щодо захисту хребетних тварин, які використовуються в експерименті та інших наукових цілях" (Страсбург, 18.03.1986 р.). Статистичну обробку експериментальних результатів для визначення біометричних показників (середні значення та їх похибки, порівняння середніх значень за критерієм Стьюдента) здійснювали 3 використанням програми Microsoft Excel-07.

\section{Результати та їх обговорення}

Імунобіологічний статус організму кролів характеризують показники неспецифічної резистентності (таблиця 1).

\section{Таблиця 1}

Показники неспецифічної резистентності організму кролів ( $\mathrm{M} \pm \mathrm{m}$ )

\begin{tabular}{cccccc}
\hline Групи тварин & $\begin{array}{c}\text { Фагоцитарна } \\
\text { активність, } \%\end{array}$ & ФІ, (од.) & ФЧ, (од.) & $\begin{array}{c}\text { Бактерицидна } \\
\text { активність, \% }\end{array}$ & $\begin{array}{c}\text { Лізоцимна } \\
\text { активність, \% }\end{array}$ \\
\hline $\begin{array}{c}\text { Здорові (контроль) } \\
\text { n = 24 }\end{array}$ & $47,38 \pm 1,10$ & $8,29 \pm 0,25$ & $3,92 \pm 0,12$ & $39,81 \pm 2,29$ & $17,48 \pm 1,61$ \\
$\begin{array}{c}\text { Хворі (дослід) } \\
\text { n = 14 }\end{array}$ & $41,82 \pm 1,51^{* *}$ & $8,22 \pm 0,42$ & $3,41 \pm 0,15^{*}$ & $26,93 \pm 3,03^{* *}$ & $16,78 \pm 1,41$ \\
\hline
\end{tabular}

Примітка:* $\mathrm{P}<0,05,{ }^{* *} \mathrm{P}<0,01$ порівняно зі здоровими тваринами

При вивченні фагоцитарної активності виявлено, що у клінічно хворих тварин вона нижча, ніж у здорових (відповідно 41,82 $\pm 1,51 \%$ проти 47,38 \pm $1,10 \%, \mathrm{P}<0,01)$. Основні клітини, які беруть участь у фагоцитозі $\epsilon$ лейкоцити, зокрема нейтрофіли та еозинофіли (Perederij et al., 1995; Maslianko \& Kravtsiv, 2007; Khariv \& Hutyi, 2017; Khariv et al., 2018). Низький показник фагоцитарної активності свідчить про пригнічений фагоцитоз в організмі тварин, хворих на цистицеркоз кролів.

Фагоцитарне число у крові кролів дослідної групи вірогідно було нижче на 0,51 одиниць $(\mathrm{P}<0,05)$ порівняно 3 контролем і корелювали 3 показником фагоцитарної активності. Важливою ланкою імунітету є показники бактерицидної та лізоцимної активності сироватки крові (Maslianko, 1999; Vishur et al., 2015). Низька бактерицидна активність сироватки крові на $12,88 \%(\mathrm{P}<0,01)$ та лізоцимна активність у кролів, хворих на Cysticercus pisiformis, також свідчать про послаблення факторів неспецифічної природної резистентності організму.

Рівень дрібних ЦІК, які переважали в кровообігу, та середніх ЦІК суттєво різнився у хворих тварин порівняно зі здоровими (рис. 1). За фізіологічних умов присутність циркулюючих імунних комплексів у рідинах є одним із проявів імунної відповіді організму кролів на надходження антигенів та важливим чинником, що забезпечує імунітет (Parahonskij, 2006).

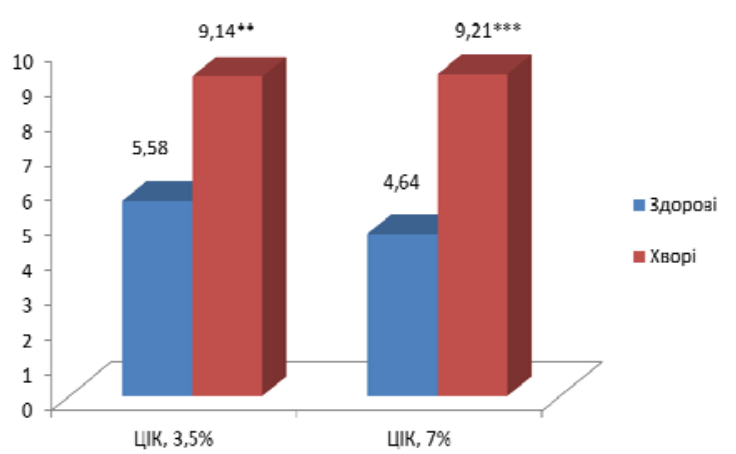

Рис. 1. Рівень циркулюючих імунних комплексів за цистицеркозної інвазії у кролів

Аналізуючи рівень циркулюючих імунних комплексів, ми встановили високий рівень середніх $(9,14 \pm 0,40$ проти $5,58 \pm 0,50)$ та дрібних $(9,21 \pm 1,35$ проти 4,64 $\pm 0,68)$ ЦІК за цистицеркозної інвазії відповідно в $1,64(\mathrm{P}<0,01)$ та 1,98 разу $(\mathrm{P}<0,001)$ проти контролю. Це свідчить про пригнічення імунобіологічної активності організму кролів внаслідок з'єднання специфічних антитіл 3 продуктами обміну гельмінтів.

\section{Висновки}

Виявлено, що у клінічно хворих тварин фагоцитарної активності вища, ніж у здорових (відповідно $41,82 \pm 1,51 \%$ проти 47,38 $\pm 1,10 \%$, $\mathrm{P}<0,01)$, при цьому фагоцитарне число у крові цих кролів вірогідно було нижче на 0,51 одиниць 
(P < 0,05) порівняно 3 контролем. Низька бактерицидна активність сироватки крові на 12,88\% (P < 0,01) у кролів, хворих на Cysticercus pisiformis, також свідчить про послаблення факторів неспецифічної природної резистентності організму.

Встановили високий рівень середніх та дрібних ЦІК за цистицеркозної інвазії відповідно в 1,64 $(\mathrm{P}<0,01)$ та 1,98 разу $(\mathrm{P}<0,001)$ проти контролю, що свідчить про пригнічення імунобіологічної активності організму кролів внаслідок з'єднання специфічних антитіл з продуктами обміну гельмінтів.

Перспективи подальших досліджень. Визначення змін рівня імуноглобулінів А, G, М за цистицеркозної інвазії.

\section{References}

Blach-Olszewska, Z., \& Jerzy, L. (2007). Mechanisms of over-activated innate immune system regulation in autoimmune and neurodegenerative disorders. Neuropsychiatr Dis Treat, 3(3), 365-372. https://www.ncbi.nlm.nih.gov/pubmed/19300567.

Das, A., Gupta, M.K., \& Saxena, R.K. (2004). Enhanced activation of mouse NK cells by IL2 in the presence of circulating immune complexes. Current science, 87(6), 780-783.

Dasso, J.F., \& Howell, M.D. (1997). Neonatal appendectomy impairs mucosal immunity in rabbits. Cellular Immunology. 182(1), 29-37. doi: 10.1006/cimm.1997.1216.

Dorofejchuk, V.G. (1968). Lizocimnaja aktivnost' syvorotki krovi. Laboratornoe delo, 1, 28-34 (in Russian).

Drouet-Viard, F.I., \& Fortun-Lamothe, L. (2002). The organisation and functioning of the immune system. particular features of the rabbit. Review. World Rabbit Science. 10, 15-23. doi: 10.4995/wrs.2002.472.

Franci, O., Amici, A., Margarit, R., Merendino, N., \& Piccolella, E. (1996). Influence of thermal and dietary stress on immune response of rabbits. Journal of Animal Science, 74(7), 1523-1529. doi: $10.2527 / 1996.7471523 x$.

Haitov, R.M., \& Pinegin, B.V. (2005). Sovremennye predstavlenija o zashhite organizma protiv infekcii. Immunologija, 1, 61-64 (in Russian).

Jeklova, E., Leva, L., Kudlackova, H., \& Faldyna, M. (2007). Functional development of immune response in rabbits. Veterinary Immunology and Immunopathology, 118(3-4), 221-228. doi: 10.1016/j.vetimm.2007.05.003.

Khariv, I., Gutyj, B., Hunchak, V., Slobodyuk, N., Vynyarska, A., Sobolta, A., Todoriuk, V., \& Seniv, R. (2017). The influence of brovitatoxide in conjunction with milk thistle fruits on the immune system of turkeys for eimeriozic invasion. Scientific Messenger LNUVMBT named after S.Z. Gzhytskyj, 19(73), 163168. doi:10.15421/nvlvet7334.
Khariv, M., Gutyj, B., Ohorodnyk, N., Vishchur, O., Khariv, I., Solovodzinska, I., Mudrak, D., Grymak, C., \& Bodnar, P. (2017). Activity of the T- and B-system of the cell immunity of animals under conditions of oxidation stress and effects of the liposomal drug. Ukrainian Journal of Ecology, 7(4), 536-541. doi: $10.15421 / 2017157$.

Khariv, M.I., \& Hutyi, B.V. (2017). Dynamika fahotsytarnoi aktyvnosti neitrofiliv u shchuriv za umov oksydatsiinoho stresu ta dii liposomalnoho preparatu. Biolohiia tvaryn, 19(1), 119-124. doi: 10.15407/animbiol19.01.119 (in Ukrainian).

Kosenko, M., Kotsiumbas, I., \& Kosenko, Yu. (2004). Kontrol vplyvu veterynarnykh likarskykh zasobiv na stan imunitetu tvaryn. Veterynarna medytsyna, 1, 4345 (in Ukrainian).

Lapovets, L.Ye., Lutsyk, B.D., Lebed, H.B., \& Akimova, V.M. (2008). Posibnyk z laboratornoi imunolohii. Lviv (in Ukrainian).

Mannapova, R.R., \& Podushkina, M.A. (2001). Imunnaja sistema pushnyh zverej i krolikov. Sovremennye imunnomorfologicheskie problemy razvitija zhivotnyh pri associativnyh infekcionno-invazionnyh zabolevanijah i ispol'zovanie dlja ih profilaktiki biologicheski aktivnyh produktov pchelovodstva. M. Sbornik nauchnyh trudov, 296-311 (in Russian).

Maslianko, R.P. (1999). Osnovy imunolohii. Lviv (in Ukrainian).

Maslianko, R.P., \& Kravtsiv, Yu.R. (2007). Funktsionalna aktyvnist neitrofilnykh hranulotsytiv u protyinfektsiinomu zakhysti tvaryn. Naukovyi visnyk LNUVM ta BT. 9(33), 185-193 (in Ukrainian).

Maslianko, R.P., Kurtiak, B.M., \& Pundiak, T.O. (2011). Imunorehuliatsiia $\mathrm{V}$ systemi mikroflora shlunkovokyshkovyi trakt. Naukovyi visnyk LNUVM ta BT imeni S.Z. Gzhytskoho, 13, 4(50), 268-275 (in Ukrainian).

Maslianko, R.P., Oleksiuk, I.I., \& Padovskyi, A.I. (2001). Metodychni rekomendatsii dlia otsinky ta kontroliu imunnoho statusu tvaryn. vyznachennia faktoriv nespetsyfichnoi rezystentnosti, klitynnykh i humoralnykh mekhanizmiv imunitetu proty infektsiinykh zakhvoriuvan. Lviv (in Ukrainian).

Parahonskij, A.P. (2006). Cirkulirujushhie immunnye kompleksy na pozdnih stadijah saharnogo diabeta. Sovremennye naukoemkie tehnologii, 1, 79-89 (in Russian).

Perederij, V.G., Zemskov, A.M., \& Bychkov, N.G. (1995). Immunnyi status, principy ego ocenki j korrekcii immunnyh narushenij. Kiev (in Russian).

Vlizlo, V.V., Fedoruk, R.S., \& Ratych, I.B. (2012). Laboratorni metody doslidzhen u biolohii, tvarynnytstvi ta veterynarnii medytsyni. Dovidnyk. za red. Vlizla, V.V. Lviv. SPOLOM (in Ukrainian).

Vishur, O.I., Hutyi, B.V., Hufrii, P.F., \& Khariv, I.I. (2015). Imunnyi status, sposoby opinky i metopy korektsii u teliat rannoho viku. Monohrafiia. Lviv, SPODOM (in Ukrainian). 